\begin{tabular}{|l|l|l||}
\hline \multicolumn{2}{|c|}{ PublisherInfo } \\
\hline \hline PublisherName & $:$ & BioMed Central \\
\hline \hline PublisherLocation & $:$ & London \\
\hline \hline PublisherImprintName & $:$ & BioMed Central \\
\hline \hline
\end{tabular}

\title{
New Pathway of NF-?B activation by TNF Described
}

\begin{tabular}{|l|l|l||}
\hline \multicolumn{2}{|c||}{ ArticleInfo } \\
\hline \hline ArticleID & $:$ & 237 \\
\hline \hline ArticleDOI & $:$ & $10.1186 /$ ar-1999-66734 \\
\hline \hline ArticleCitationID & $:$ & 66734 \\
\hline \hline ArticleSequenceNumber & $:$ & 194 \\
\hline \hline ArticleCategory & $:$ & Paper Report \\
\hline \hline ArticleFirstPage & $:$ & 1 \\
\hline \hline ArticleLastPage & $:$ & 3 \\
\hline \hline & $:$ & RegistrationDate : 1999-10-11 \\
ArticleHistory & $:$ & OnlineDate $1999-10-11$ \\
\hline \hline ArticleCopyright & $:$ & Current Science Ltd1999 \\
\hline \hline ArticleGrants & $:$ & \\
\hline \hline ArticleContext & $:$ & 130753311 \\
\hline \hline
\end{tabular}


Aff1 United Medical and Dental Schools of Guy's and St Thomas' Hospital, London, UK

\section{Keywords}

\section{Akt serine-threonine kinase, apoptosis, NF-?B, NF-?B-inducing kinase, TNF}

\section{Context}

The nuclear factor NF-?B controls the expression of many genes and has been shown to play a role in inflammation, coagulation and apoptosis. Under normal conditions NF-?B is bound to its inhibitor I?B, and the complex remains in the cytoplasm. Degradation of the I?B leaves NF-?B free to cross the nuclear membrane and bind to the promoter regions of genes and activate transcription. Tumour necrosis factor (TNF) is known to initiate one pathway for NF-?B activation. Association of TNF with TNFR1 causes the formation of a complex involving TRAF2 and NIK, which results in NF-?B activation through degradation of its inhibitor. Binding of TNF to TNF receptor type 1 (TNRF1) also activates phosphatidylinositol-3-OH kinase (PI3K), which in turn activates the serine/threonine kinase Akt. As activated Akt is formed through a branch of the TNF pathway, the authors sought to identify whether this also plays a role in activation of NF-?B.

\section{Significant findings}

Lipid kinase activity of PI(3)K increased within 5 min of TNF stimulation and was maximal at 20 min. Probing Western blots of proteins from 293 cells with antibody to activated (phosphorylated) Akt revealed a temporal correlation with $\mathrm{PI}(3) \mathrm{K}$ activity, an effect blocked by wortmannin. Dominantnegative $\mathrm{PI}(3) \mathrm{K}$ transfection abrogated the 2.3-fold increase in Akt activity.

EMSA studies showed NF-?B activity in response to TNF stimulation and inhibition by wortmannin. Activity was enhanced by transient transfection with constitutively active PI(3)K or constitutively active Akt or NIK. Cotransfection of NIK with constitutively active Akt or PI(3)K produced an additive effect on NF-?B binding to DNA, while dominant negative PI(3)K inhibited NF-?B activation and dominantnegative NIK or wortmannin abrogated PI(3)K activation of NF-\&?B. While constitutively active Akt alone promoted NF-?B binding to DNA, kinase-dead Akt inhibited it, showing Akt to be essential for NF-?B activation. However, dominant-negative NIK inhibited the effect of constitutively active Akt, and NF-?B activation by NIK was inhibited by kinase-dead Akt. Thus, NF-?B activation requires both 
Akt and NIK and the results from EMSA were confirmed using reporter assays for NF-?B-dependent gene activity. Constitutively active Akt increases gene activity more than four fold.

\section{Comments}

TNF is a proinflammatory cytokine, which is itself a promising target for immunomodulatory therapy in autoimmune disease. This paper demonstrates the presence of a hitherto unrecognised pathway of NF?B activation by TNF. This new link between proinflammatory cytokines and the genes that control apoptosis will add to our understanding of the complexities of cell death, which is relevant to numerous disease processes.

\section{Methods}

Embryonic kidney 293 cells and ME-180 human cervical carcinoma cells were used to investigate, by time-course, the lipid-kinase activity of PI(3)K following stimulation by TNF. Then Western blots were probed for phosphorylated (activated) and nonphosphorylated Akt in the presence or absence of wortmannin, an inhibitor of PI(3)K. In addition cells were transfected with a dominant-negative PI(3)K, to determine whether Akt is downstream of PI(3)K.

To investigate the intracellular pathway further, NF-?B binding to DNA was assessed using electrophoretic mobility shift assay (EMSA) in the presence or absence of wortmannin, constitutively active PI(3)K and constitutively active Akt and NIK. Also, co-transfection experiments were performed, using NIK with constitutively active PI(3)K or constitutively active Akt as well as dominant-negative PI(3)K with NIK, and dominant-negative NIK and wortmannin with PI(3)K. Kinase-dead and constitutively active Akt in the presence and absence of dominant-negative NIK were compared. NF-?B reporter assays were used to confirm the results from EMSA.

\section{References}

1. Ozes ON, Mayo LD, Gustin JA, Pfeffer SR, Pfeffer LM, Donner DB: NF-?B activation by tumour necrosis factor requires the Akt serine-threonine kinase. Nature. 1999, 401: 82-85.

This PDF file was created after publication. 